\title{
Study of Effects on Potency and Fatigability of Muscle Develop in People WHO Gym Consuming Whey Protein (Supplement) with Compared to Consuming Meat, Fish and Eggs (Natural Protein)
}

\author{
Varad Gondhali', Ranjit Ambad², Ninad Nagrale ${ }^{3}$, Nandkishor Bankar ${ }^{4}$ \\ ${ }^{1}$ First Year MBBS Student Datta Meghe Medical College, Shalinitai \\ Meghe Hospital and Research Centre, Nagpur, India \\ ${ }^{2}$ Department of Biochemistry Datta Meghe Medical College, Shalinitai Meghe \\ Hospital and Research center, Nagpur, India \\ ${ }^{3}$ Department of Forensic Medicine Datta Meghe Medical College, Shalinitai Meghe \\ Hospital and Research center, Nagpur, India \\ ${ }^{4}$ Department of Microbiology, Jawaharlal Nehru Medical College, Datta Meghe \\ Institute of Medical Sciences Sawangi (Meghe), Wardha \\ Corresponding author email: ambad.sawan@gmail.com
}

\begin{abstract}
The study was conducted to check if there is any variation in muscle strength and fatigability in people who gym consuming whey protein (supplement) in comparison to those consuming meat, fish and eggs. Participants were divided into two groups: Group A with whey protein consumers and Group B with normal diet consumers. BMI was calculated both the type of the consumer and Muscle strength was measured with the help of hand grip dynamometer and fatigability with Mosso'sergogram. The results came out to be inconclusive showing no significant variation in terms of strength and fatigability in the two groups. Because of the same time the group were not formed and gym time were quite different. Now The questions follow that can a better result be obtained if the time period in gym of each group was same? Study of Effects on Potency And Fatigability Of Muscle Develop In People Who Gym Consuming Whey Protein (Supplement) With Compared To Consuming Meat, Fish And Eggs (Natural Protein) Based on the results obtained, the research is inconclusive, and was unable to find any significant variation in terms of strength and fatigability in whey protein consumers and normal diet consumers. Further research in terms of selecting individual participants who would start the gym at the same time and then form a part of the two groups of whey protein consumers and normal diet consumers, allowing equal amount of gym time would be able to interpret the result more appropriately.
\end{abstract}

KEY WORDS: PROTEIN,MEAT, FISH AND EGGS.

\section{INTRODUCTION}

(Fowler et al., 1992)Muscle strength refers to the quantity of force a muscle will turn out with one highest effort or

Biosc Biotech Res Comm P-ISSN: 0974-6455 E-ISSN: 2321-4007

\section{crossef}

Identifiers and Pagination

Year: 2021 Vol: 14 No (6) Special Issue

Pages: 298-302

This is an open access article under Creative

Commons License Attribn 4.0 Intl (CC-BY).

DOI: $h t t p: / / d x . d o i . o r g / 10.21786 / b b r c / 14.6 .63$ the most force or tension generated bay muscle. (Fowler et al. 1992) Muscle weakness is decline within the ability of a muscle to generate force. Muscular strength is that the quantity of force you'll be able to place out or the quantity of weight you'll be able to carry. (Strasunskas et al., 2020) Muscular endurance is what percentage times you'll be able to move that weight while not obtaining exhausted (very tired).

parts of milk has casein and whey, from that the substance named 'Whey'. Whey macromolecule could be a mixture of proteins isolated from whey, that is that the liquid a part of milk that separates throughout cheese production.

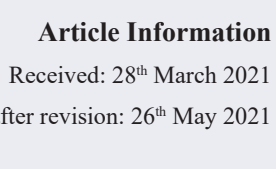

Article Information
Received: $28^{\text {th }}$ March 2021

ccepted after revision: $2^{\text {th }}$ May 2021 
Milk really contains 2 main kinds of protein: casein $(80 \%)$ and whey $(20 \%)$. Whey is found within the watery portion of milk. and for the muscle development the macromolecule intake ought to be high. also, the whey macromolecule contains the essential amino acids, together with essential amino acid and amino acid. (Rasheed et al., 2020) Skeletal muscles area unit those that area unit connected to bones, tendons, and that they offer movement to all or any body elements. musculus is capable of adapting to a progressive high resistance coaching regime by increasing its size and strength (hypertrophy). The dietary set up for muscle improvement is high dose of macromolecule intake that is provided by Whey macromolecule however may be obtained by naturally out there high macromolecule diet is that the whey macromolecule prove issue as a result of its composition is simply macromolecule however our body also want different micronutrients which may be obtained by the natural supply.

If we tend to use whey macromolecule as intake mass development can take few months however natural macromolecule would take many months as per the productivity whey macromolecule supplementation use for muscle building and quality of muscle is developed by supplementation muscles efficiency and fatigue area unit obvious thanks to that muscle development occur in brief length effective developed by traditional diet is that the question that has to be answered. the different status instruments area unit a viable however to perform there's underrated that the analysis instruments use is hand grip ergometer and Mosso's ergogram, these explicit instruments area unit chosen even if several others area unit out there as a result of \{they area they're noninvasive several studies are done on whey macromolecule however basic level of study like efficiency and weakness aren't done style of study is predicated on choice on candidates UN agency slot in the dietary protocol calculation BMI muscle strength (in $\mathrm{kg}$ ) and weakness (in sec) by mistreatment the several instruments area unit whey macromolecule supplementation offer same edges as traditional diet set up or constant muscle building on traditional diet be higher to require whey macromolecule supplementation?.

Review of Literature: (Spillane et al., 2014)The study design is on we aremaking two group one with normal diet consumer and other with whey protein consumer. (Macnaughton et al. 2016) Considering thisparameters whey protein are consume and normal diet intake are calculating BMI of the consumer in study and weekly calorie intake (Kcal / week) that affect result. (Pallavi et al., 2017)) thus, Method used is Mosso's ergogram and handgrip dynamometer for getting muscle fatigability and potency respectively of the particular person.

\section{Aims and Objectives}

1. To assess the strength of skeletal muscleusing hand grip dynamometer.

2. To assessthefatigability of skeletal muscle using Mosso's ergogram.
3. To compare the aboveparameters in whey protein users and people withnormal diet intake.

\section{MATERIAL AND METHODOLOGY}

1. Type of Study: This was a cross sectional study.

2. Study Settings: The study was conducted in nearby Gym centres in Nagpur.

3. Sample Size: Sample size of 80 (40 in each group)

4. Selection Criteria: The participants were selected on the basis of few inclusion and exclusion criteria.

5. The Inclusion Criteria: $\neg-$

- $\quad$ Should be between 18 to 35 years of age.

- Should have been going to gym for a period of at least 2 months.

- Male gender in order to avoid variations related to gender.

- Should have been using supplementation (whey protein) along with normal food for Group A

- Should have been using only meat, fish and eggs for increase in protein for Group B.

- Willing to participate.

- $\quad$ BMI between 18.5 to $28 \mathrm{~kg} / \mathrm{m} 2$.

\section{The Exclusion Criteria}

- People with documented cases anaemia and other fatigability disorders are to be avoided.

- Not willing to participate.

- Also, the age bar person

Study Design: The study proposal was submitted to Institutional Ethical Committee (IEC) and research was carried out after its approval. Present study was conducted among people satisfying theinclusion criteria. The study participants were recruited from the nearby Gym centres in Nagpur.Permission to conduct study from the appropriate authorities will be obtained. Written informed consent was taken from all the study participants. Strengthwas measured using a hand grip dynamometer and fatigability using Mosso's ergograph. Height and weight were taken and BMI was calculated. Their weekly average dietary intake was also calculated in terms of calories (Kcal) with the help of 'Approximate Calorific value of cooked preparation table’.

Research Instrument: Hand grip dynamometer was used to measure the maximum isometric strength of the hand and forearm muscles.

1. Participant were asked to hold the dynamometer in the hand to betested (preferably the dominanthand) with theelbow at rightangles and arm by the side of the body.

2. The handle of the dynamometer was adjusted as required, when ready participant is asked to squeezethe dynamometer with maximum isometric effort whichis maintained for 5 seconds

3. at the time of examine no other body movements were allowed.

Mosso's Ergograph was used to calculate the time take for a muscle to get fatigued. 
1. The instrument was kept on a table of suitable height. Participant was asked to sit comfortably on a stool and to hold the vertical rod with fingers.

2. The cuffs were moved inward so as to hold the wrist firmly. Suitable weight was puton the weight stand and the strip of paper wasadjusted withthe writingpencil properly

3. Metronome was set at rate of 120 per minute. Middle finger was put in the sling and the subject was asked to pull the weight at 60 per minute till the finger is fatigued. $3 \mathrm{~kg}$ weight was set as standard for all the readings

\begin{tabular}{|c|c|c|c|c|}
\hline Code & $\mathrm{N}$ & Mean & Std. Deviation & Std. Error Mean \\
\hline $\begin{array}{l}\text { Age } \\
1 \\
2\end{array}$ & $\begin{array}{l}40 \\
40\end{array}$ & $\begin{array}{l}25.7000 \\
25.0750\end{array}$ & $\begin{array}{l}5.80981 \\
4.80591\end{array}$ & $\begin{array}{l}.91861 \\
.75988\end{array}$ \\
\hline $\begin{array}{l}\text { Height(cm) } \\
1 \\
2\end{array}$ & $\begin{array}{l}40 \\
40\end{array}$ & $\begin{array}{l}172.8375 \\
173.5875\end{array}$ & $\begin{array}{l}5.13458 \\
6.38195\end{array}$ & $\begin{array}{c}.81185 \\
1.00908\end{array}$ \\
\hline $\begin{array}{l}\text { Weight }(\mathrm{Kg}) \\
1 \\
2\end{array}$ & $\begin{array}{l}40 \\
40\end{array}$ & $\begin{array}{l}73.0725 \\
72.1275\end{array}$ & $\begin{array}{c}8.38913 \\
11.73207\end{array}$ & $\begin{array}{l}1.32644 \\
1.85500\end{array}$ \\
\hline $\begin{array}{l}\text { BMI }(\mathrm{kg} / \mathrm{m} 2) \\
1 \\
2\end{array}$ & $\begin{array}{l}40 \\
40\end{array}$ & $\begin{array}{l}24.4313 \\
23.8460\end{array}$ & $\begin{array}{l}2.30610 \\
2.98636\end{array}$ & $\begin{array}{l}.36463 \\
.47218\end{array}$ \\
\hline $\begin{array}{l}\text { Strength(kg) } \\
1 \\
2\end{array}$ & $\begin{array}{l}40 \\
40\end{array}$ & $\begin{array}{l}56.3000 \\
53.9250\end{array}$ & $\begin{array}{l}13.25528 \\
16.09170\end{array}$ & $\begin{array}{l}2.09584 \\
2.54432\end{array}$ \\
\hline $\begin{array}{l}\text { Fatigability(sec) } \\
1 \\
2\end{array}$ & $\begin{array}{l}40 \\
40\end{array}$ & $\begin{array}{l}32.3500 \\
31.5000\end{array}$ & $\begin{array}{l}11.42546 \\
8.83466\end{array}$ & $\begin{array}{l}1.80652 \\
1.39688\end{array}$ \\
\hline $\begin{array}{l}\text { Dietary (Kcal/week) } \\
1 \\
2\end{array}$ & $\begin{array}{l}40 \\
40\end{array}$ & $\begin{array}{l}13069.3500 \\
11536.6750\end{array}$ & $\begin{array}{l}5928.43435 \\
3817.17150\end{array}$ & $\begin{array}{l}937.36777 \\
603.54781\end{array}$ \\
\hline
\end{tabular}

Statistical Test used: Independent T test was used

Observation and Results: The participants in group a (supplement users) had a mean age of $25.7+5.8$ and of group B (normal diet) had $25.07+4.8$. Group A had mean BMI of $24.43+2.3$ and group B with 24.84 +2.98 . The weekly dietary intake of group $A$ and $B$ were $13069.35+5928.43$ and $11536.67+3817.17$. The parameters that had to be compared that is strength and fatigability were, strength $56.30+13.25$ in group A and $53.92+16.09$ in group B whereas fatigability in group A was $32.35+11.42$ and in group B was $31.50+8.83$ as shown in the table below.

\section{DISCUSSION}

Differing from the initial hypothesis that whey macromolecule customers could have less strength or weakness as compared to traditional diet users, the result came out to be having no important variation in terms of strength and weakness in each teams because the whey macromolecule consumwer square measure showing weak performance as a result of accrued intestine movements, cramps, reduced appetence, weariness (fatigue), nausea, bloating, thirst and headache. As per the natural diet it doesn't have an effect on a lot of to the body it helps a lot of for the muscle development for the efficiency and also the weakness of the body though the study style was straightforward and will analyse the specified parameters, the restrictions in terms of 'Time period' since once these individuals athletic facility couldn't be assessed conjointly the uniformity between every client for doing athletic facility exercise ought to be also same to urge exercise correct calculation and also the conclusion.

So, the variation in terms of the time since once the individual used to athletic facility and therefore to acquire a sample with equal time in athletic facility wasn't potential. A higher study style would be to choose participants UN agency would begin to athletic facility as a part of analysis, then consume equal quantity of whey macromolecule to it of traditional dietary macromolecule so every cluster can have an equivalent fundamental quantity in athletic facility, would are a lot of acceptable. (Gadbail et al., 2019) Secondly, the sort of exercise drained athletic facility may additionally have an effect on the higher than parameters; some could do higher body exercises a lot of whereas some could improve lower body. 
Because the athletic facility each exercise uses totally different muscles strength and weakness that the uniformity wasn't gift between them that the calculation was showing the distinction however the conventional diet client was showing the soul efficiency of the muscles conjointly the re ought to be uniform elbow grease done of client to urge muscle development for the higher result and also there ought to same elbow grease given by the athletic facility trainer to the client and the work shouldn't be an excessive amount of that there muscle can get fatigue and there'll not be correct exercise and the they are available within the proper inclusion criteria of the analysis like the BMI of the candidates within the study and also the weekly calorie intake (Kcal/week) which could have an effect on the results of the analysis that the consumer ought to within the observatory concerning their intakes and there compute set up. and correct diet like whey macromolecule and also the natural diet can create their correct spare mass development of the buyer and there ought to be lost the right intake concerning the macromolecule diet as a result of person to person the macromolecule dietary changes also because the compute of athletic facility too however while not obtaining any aspect result.

Table 2

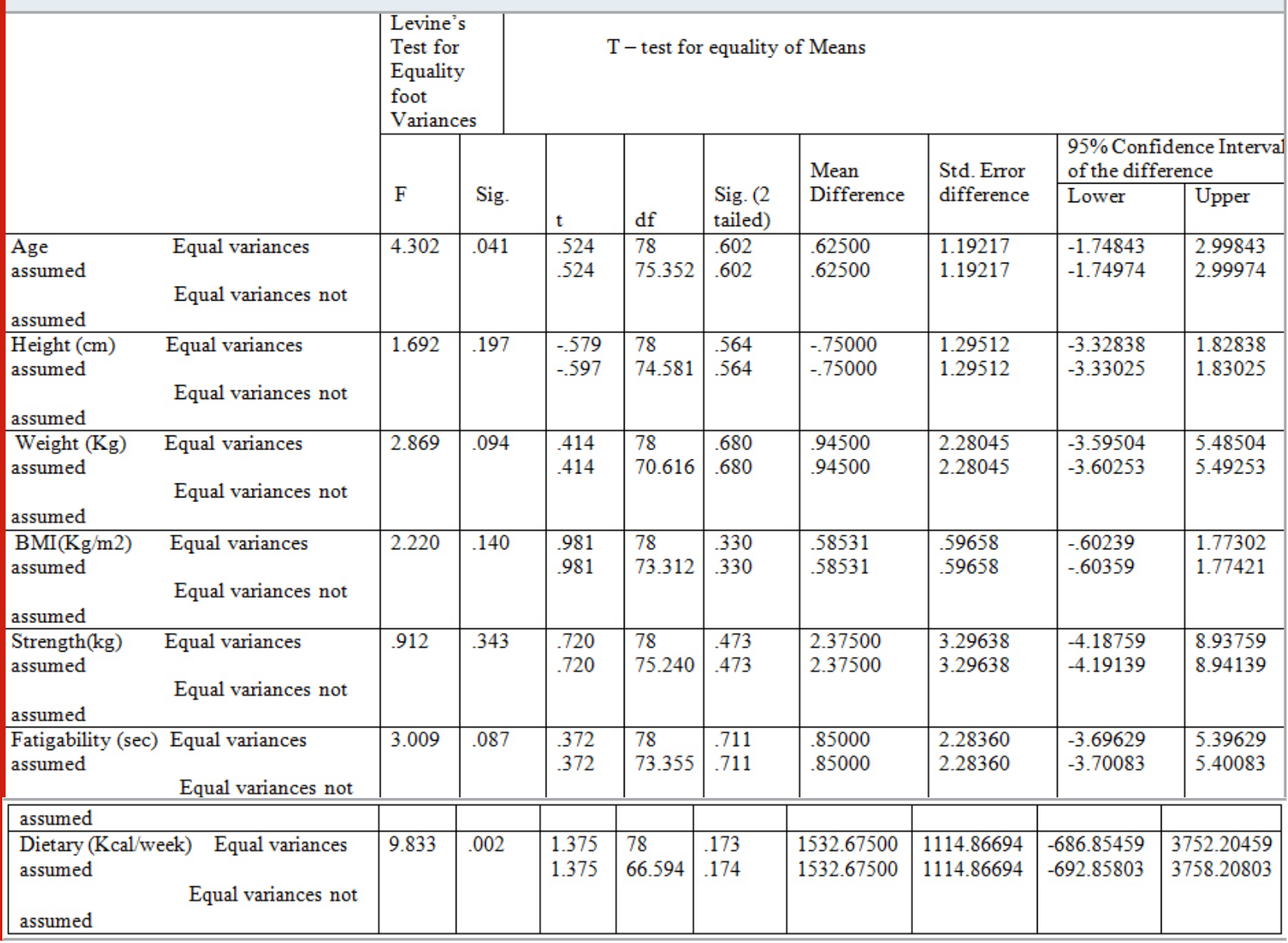

\section{CONCLUSION}

Based on the results obtained, the research isinconclusive, and was unable to find any significant variation in terms of strength and fatigability in whey protein consumers and normal diet consumers. Further research in terms of selecting individual participants who would startthe gym at the same time and then form a part ofthe two groups of whey protein consumers and normal diet consumers, allowing equal amount of gym time would be able to interpret the result more appropriately.

\section{REFERENCES}

Fowler, J.A., 1992. Exercise Physiology: Energy, nutrition and human performance. Physiotherapy, 78(2), p.148.

Gadbail, A.R., Chaudhary, M.S., Sarode, S.C., Gondivkar, S.M., Belekar, L., Mankar-Gadbail, M.P., Dande, R., Tekade, S.A., Yuwanati, M.B. and Patil, S., 2019. Ki67, CD 105 and $\otimes$-smooth muscle actin expression in disease progression model of oral submucous fibrosis. Journal of investigative and clinical dentistry, 10(4), p.e12443.

Latchoumi, T.P., Ezhilarasi, T.P. and Balamurugan, K., 2019. Bio-inspired weighed quantum particle swarm optimization and smooth support vector machine ensembles for identification of abnormalities in medical data. SN Applied Sciences, 1(10), pp.1-10. 
Macnaughton, L.S., Wardle, S.L., Witard, O.C., McGlory, C., Hamilton, D.L., Jeromson, S., Lawrence, C.E., Wallis, G.A. and Tipton, K.D., 2016. The response of muscle protein synthesis following whole-body resistance exercise is greater following $40 \mathrm{~g}$ than $20 \mathrm{~g}$ of ingested whey protein. Physiological reports, 4(15).

Pallavi, L.C., SoUza, U.J.D. and Shivaprakash, G., 2017. Assessment of musculoskeletal strength and levels of fatigue during different phases of menstrual cycle in young adults. Journal of clinical and diagnostic research: JCDR, 11(2), p.CC11.
Rasheed, A., Acharya, S., Shukla, S., Kumar, S., Yarappa, R., Gupte, Y. and Hulkoti, V., 2020. High-Sensitivity C-Reactive Protein in Metabolic Healthy Obesity (MHO)..

Spillane, Mike, Neil Schwarz, and Darryn S. Willoughby. "Heavy resistance training and peri-exercise ingestion of a multi-ingredient ergogenic nutritional supplement in males: effects on body composition, muscle performance and markers of muscle protein synthesis." Journal of sports science \&t medicine 13, no. 4 (2014): 894.

Strasunskas, D., 2020. Impact of strength training on basketball athletes (Doctoral dissertation). 